\title{
Сравнения в якутском и тувинском эпосах: общее и специфичное
}

\author{
Сахая Д. Львова \\ Северо-Восточный федеральный университет имени М. К. Аммосова, \\ Российская Федерация

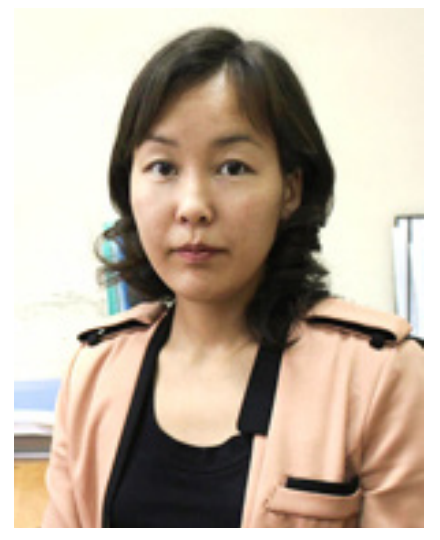 \\ В статье рассматриваются сравнительные структуры, присутствующие в тек- \\ стах якутских олонхо «Кыыс Дэбилийэ» (сказителя Н. П. Бурнашева), «Могучий Эр \\ Соготох» (сказителя В. О. Каратаева) и тувинских эпосов «Хунан-Кара» (сказителя \\ Ч.-Х. Ч. Ооржака), «Боктуг-Кириш, Бора-Шэлей» (сказителя М. Н. Ооржака). Цель ис- \\ следования - установление общности и особенностей в использовании сравнения как \\ речевого средства эпической образности по материалам текстов родственных тюрк- \\ ских народов - тувинцев и якутов. Основным методом исследования является ком- \\ паративный анализ. Классификация сравнений по тематическим группам объектов и \\ образов основана на систематизации Ф. М. Селиванова, примененной в изучении срав- \\ нений русских былин. \\ Методом сплошной выборки из эпических текстов выявлено сравнительных кон- \\ струкций 317 единиц из якутского и 199 из тувинского материалов. Количественные \\ показатели частотности сравнений, процентное соотношение их параллелизации \\ и тематических групп компонентов сравнения выведены методом статистическо- \\ го анализа. Установлено, что сравнение в якутском олонхо употребляется чаще, чем \\ в тувинском. В обоих эпосах сравнения главным образом оформляются в двухчленные \\ параллелизмы (более 90\%). Определены кониепты основных устойчивых сравнений эпосов. \\ Основное внимание уделено составу компонентов сравнения, семантике и функции образов. Обнаружены паралле- \\ ли сравнений по ассоциациям и по образам. Сопоставительный анализ объектов и образов сравнения выявил большую \\ архаичность тувинских сравнений. Материал якутского олонхо отличается обилием биоморфных образов и образов, \\ выражающих национальную специфику, которые считаются более поздними, сложившимися после переселения в Яку- \\ тию. Установлено, что сравнение в тувинских текстах в основном привлечено с целью гиперболизации численности \\ или размера объекта, а в якутском олонхо основной функцией сравнений является передача яркого зрительного образа. \\ В материалах обоих эпосов определены образы, отражающие культурно-бытовые реалии и географические особенности \\ среды обитания народа-носителя эпоса.
}

Ключевые слова: тюркский эпос; якутское олонхо; тувинский эпос; якутский фольклор; тувинский фольклор; якуты; тувинцы; якутский язык; тувинский язык; речевое средство; эпическая образность; сравнение; образ сравнения; объект сравнения

\section{Финансирование}

Исследование выполнено в рамках научно-исследовательского проекта СВФУ «Эпический памятник нематериальной культуры якутов: текстологический, типологический, когнитивный и историко-сравнительный аспекты».

Для цитирования:

Львова С. Д. Сравнения в якутском и тувинском эпосах: общее и специфичное // Новые исследования Тувы. 2021, № 1. C. 202-216. DOI: https://www.doi.org/10.25178/nit.2021.1.11

Львова Сахая Даниловна - старший научный сотрудник - заведующий сектором «Олонховедение» Научно-исследовательского института Олонхо Северо-Восточного федерального университета имени М. К. Аммосова. Адрес: 677000, Россия, г. Якутск, ул. Белинского, д. 58. Тел.: +7 (914) 225-30-29. Эл. адрес: lvovasd85@gmail.com

LVOVA, Sakhaya Danilovna, Senior Researcher, Head of the Sector "Olonkho Studies" of the Olonkho Research Institute, NorthEastern Federal University. Address: 677000, Russia, Yakutsk, st. Belinsky, 58. Tel.: +7 (914) 225-30-29. E-mail: lvovasd85@gmail.com 


\title{
Comparisons in the Yakut and Tuvan epics: general and specific
}

\author{
Sakhaya D. Lvova \\ M. K. Ammosov North-Eastern Federal University, \\ Russian Federation
}

The article examines comparative structures in the texts of the Yakut olonkho "Kyys Debiliie" (as told by storyteller N. P. Burnashev), "Mighty Er Sogotokh" (by V. O. Karataev) and Tuvan epics "Khunan-Kara" (by Ch.-Kh. Ch. Oorzhak) and "Boktug-Kirish, Bora-Shelei" (by M. N. Oorzhak). The aim of the study is to discover both common and distinctive features in the use of comparisons and similes as a linguistic means of epic imagery based on the materials of the texts by Turkic peoples - Tuvans and Yakuts. Working within comparative method, the authors offer a classification of comparisons by thematic groups of objects and images, based on the systematization suggested by F. M. Selivanov in his study of comparisons in Russian bylinas.

The method of continuous sampling from epic texts revealed 317 comparative constructions in Yakut and 199, in Tuvan texts. Quantitative indicators of the frequency of comparisons, as well as the percentage of their parallelization and thematic groups of simile components are calculated with the use of statistical analysis. It was found that the comparison is used more often in the Yakut olonkho than in the Tuvan ones. In both epics, comparisons are mainly formed as two-term parallelisms (more than 90\%). Also determined are the concepts behind the main stable comparisons in the epics.

The main attention in the work was paid to the composition of simile components, semantics, and function of images. Parallels between in associations and images in the similes were found. A comparative analysis of objects and images revealed largely archaic character of Tuvan similes. Their counterparts in the Yakut olonkho are distinguished by an abundance of biomorphic images, probably formed after they resettled in Yakutia. It has been discovered that similes in Tuvan texts are mainly used to exaggerate the number or size of an object, and in the Yakut olonkho the main function of comparisons is to convey a vivid visual image. In the materials of both epics, images are defined that express national specifics and reflect the geographical features of the habitat of the people who created this epic.

Keywords: Turkic epics; Yakut olonkho; Tuvan epics; Yakut folklore; Tuvan folklore; Yakuts; Tuvans; Yakut language; Tuvan language; speech means; epic imagery; simile; comparison image; object of comparison

\section{Financing}

This research has been conducted as part of the scientific-research project NEFU "Epic monument of the Yakut intangible culture: textological, typological, cognitive and historical-comparative aspects”.

\section{For citation:}

Lvova S. D. Comparisons in the Yakut and Tuvan epics: general and specific. New Research of Tuva, 2021, no. 1, pp. 202-216. (In Russ.). DOI: https://www.doi.org/10.25178/nit.2021.1.11

\section{Введение}

В поэтике фольклорного произведения важная роль отводится изобразительно-выразительным средствам, среди которых одним из наиболее ранних считается сравнение. Сравнение - речевое средство эпической образности, которое уподобляет изображаемое явление другому по какому-либо общему для них признаку с целью выявить в объекте сравнения новые, важные свойства (Литературный энциклопедический ..., 1987: 418). Оно является наиболее распространенным средством выразительной речи эпоса и особенностью человеческого мышления, способом познания и представления эпической картины мира. А так как эпос является коллективным произведением, помимо индивидуальных особенностей мастерства отдельного сказителя, сравнения могут охарактеризовать национально-специфическое видение мира целого народа.

В работе И. В. Пухова одним из показателей, подтверждающих генетическую общность эпического творчества алтае-саянских народов и якутов, было указано сходство приемов описания, характеристики и изобразительных средств (Пухов, 2004: 290). Исследователем тогда были установлены сходства в сравнениях якутского и алтайского эпосов. В развитие начатой И. В. Пуховым темы, нами были проведены компаративные исследования сравнений родственных якутского, алтайского, хакасского 
и шорского эпосов (Gerasimova, Lvova, 2018; Львова, 2019; Lvova, 2020). В настоящей же статье представлены основные результаты сопоставительного изучения сравнений якутского и тувинского эпосов. Цель исследования - установление общности и отличий в использовании сравнений в эпических произведениях якутов и тувинцев, которые являются представителями тюркской группы народов России. Актуальность исследования определяется возрастающим интересом к сопоставительному изучению языка и поэтики эпосов родственных народов, их генезису.

Исследование основывается на теоретических положениях отечественных фольклористов: Ф. М. Селиванова (Селиванов, 1977), А. В. Кудиярова (Кудияров, 2002), В. П. Аникина (Аникин, 2007), С. М. Орусоол (Орус-оол, 2001), Л. Ц. Санжеевой (Санжеева, 2011), Л. К. Хертек (Хертек, 2018), приняты во внимание актуальные работы последних лет, посвященные компаративному изучению якутского и тувинского эпосов (Борисов, 2020; Корякина, 2020; Саввинова, 2020). Основной материал исследования составляют лучшие образцы эпических текстов, опубликованные в томах двуязычной серии «Памятники фольклора народов Сибири и Дальнего Востока»: якутские олонхо «Кыыс Дэбилийэ» Н. П. Бурнашева (Бурнашев, 1993), «Могучий Эр Соготох» (якут. «Модун Эр Соқотох») В. О. Каратаева (Каратаев, 1996) и тувинские героические сказания «Хунан-Кара» Ч.-Х. Ч. Ооржака (Ооржак Ч.-Х., 1997), «Боктуг-Кириш, Бора-Шэлей» (тув. «Боктуг-Кириш, Бора-Шээлей») М. Н. Ооржака (Ооржак М., 1997). При выборе материала исследования имели значение следующие критерии. Во-первых, это наличие русского перевода: начальная выборка сравнительных конструкций осуществлялась на материале переводных текстов тувинского эпоса, далее была проведена сверка с оригиналами текстов с помощью тувинско-русских и русско-тувинских словарей с целью подтверждения предполагаемых сравнений или исключения продуктов художественного перевода. Второй критерий - относительно одинаковые объемы текстов, третий - их запись в один временной период (середина XX в.). И, в-четвертых, это принадлежность к одному типу эпического произведения по главному герою - в материалах каждого эпоса выбраны тексты с героем-богатырем и женщиной-воительницей. Также стоит отметить, что тексты тувинского «Боктуг-Кириш, Бора-Шэлей» и якутского «Могучий Эр Соготох» являются самозаписями сказителей.

Статистические данные исследования выведены на материале указанных четырех текстов. Для анализа состава объектов и образов сравнений, поиска их параллелей дополнительно привлекаются тексты ранних записей олонхо на якутском языке: «Эриэдэл Бэргэн» в записи А. Ф. Миддендорфа 1844 г. (Миддендорф, 1911), «Хаан Дьаргыстай», записанный И. А. Худяковым в конце 1860-х гг. (Хаан Дьаргыстай, 2016).

\section{Результаты статистического анализа}

Сравнительные конструкции для анализа отобраны посредством сплошной выборки из эпических текстов. Количественные показатели применения сравнения в эпосах отражены в табл. 1.

Таблица 1. Показатели использования сравнения в текстах якутского и тувинского эпосов. Table 1. Indicators of the use of comparison in the texts of the Yakut and Tuvan epics.

\begin{tabular}{|l|c|c|c|c|}
\hline & \multicolumn{2}{|c|}{ Якутские эпосы } & \multicolumn{2}{|c|}{ Тувинские эпосы } \\
\cline { 2 - 5 } & $\begin{array}{c}\text { «Кыьс } \\
\text { Дэбилийэ» }\end{array}$ & $\begin{array}{c}\text { «огучий Эр } \\
\text { Соготох» }\end{array}$ & $\begin{array}{c}\text { «Боктуг- } \\
\text { Кириш, } \\
\text { Бора-Шэлей» }\end{array}$ \\
\hline Год записи & 1941 & 1982 & 1959 & 1962 \\
\hline Объем текста (стих. строки)* & 4969 & 6377 & 5442 & 5061 \\
\hline Общее кол-во употребления сравнения & 157 & 161 & 109 & 90 \\
\hline Кол-во сравнений без повторов & 134 & 74 & $\mathbf{6 5}$ & $\mathbf{4 5}$ \\
\hline $\begin{array}{l}\text { Максимальное кол-во употребления одного } \\
\text { устойчивого сравнения }\end{array}$ & 6 & 9 & 5 & 8 \\
\hline Кол-во употребленных единожды сравнений & 85 & 25 & 28 & 25 \\
\hline
\end{tabular}

Прим.: *данные соотносимы и с оригиналами текстов, и с переводными текстами. 
Частотность употребления сравнений выведена с учетом объемов эпических текстов (количества стихотворных строк): в якутском олонхо коэффициенты употребления сравнения составляют 32 (1 сравнение на 32 строки) и 40; в тувинском эпосе эти показатели равны 50 и 56 . Количество сравнений, не считая повторов, чуть выше в якутских олонхо.

Отмечена высокая частотность и разнообразие сравнений в якутском тексте «Кыыс Дэбилийэ».

Показатели по количеству употребления устойчивых сравнений и неповторяемых сравнений в эпосах оказались примерно одинаковыми. Далее рассмотрена параллелизация сравнений по текстам «Могучий Эр Соготох» и «Боктуг-Кириш, Бора-Шэлей», в результате чего установлено следующее. В якутском олонхо 65\% сравнений входят в состав параллелизмов. Это всего 48 параллелизмов, в т. ч.: двухчленные параллелизмы - 43 единицы (90\%), трехчленные -2 , четырехчленные -3 . В тувинском эпосе параллелизации подвергнуто 59\% сравнений: всего 25 параллелизмов, из них двухчленных параллелизмов - 23 единицы (92\%), а трехчленных и четырехчленных выявлено по одному случаю. Таким образом, в рассмотренных текстах отмечается высокая популярность двухчленного параллелизма, что свойственно всем тюркским эпосам (Львова, 2019: 129).

\section{Функции сравнений}

Функции сравнений в рассматриваемых эпосах условно разделяются на три группы. Мы говорим об условности, поскольку между ними отсутствуют четкие границы, а также одно сравнение одновременно может выполнять несколько функций. Можно выделить и дополнительные группы, но в связи с локальным характером материала исследования ограничимся тремя группами по доминирующим функциям: 1) передача численности, размера, объема, толщины объекта; 2) картинное изображение объекта (вид, цвет, фигура и др.); 3) описание движений и действий объекта.

В тувинском тексте «Хунан-Кара» 35\% сравнений употребляется для обозначения численности, размера, объема объекта. При этом большая часть из них (78\%) использована для гиперболизации какой-либо величины. Например, в тексте «Хунан-Кара» гиперболизируется численность: 1) лошадей посредством сравнения с количеством волос человека, 2) скота - с растениями караганы, 3) сражений с шерстью трех или девяти собак; а в тексте «Боктуг-Кириш, Бора-Шэлей» отмечены следующие преувеличения численности: 4) люди - мухи, муравьи, травы, деревья в лесу; 2) кони - густой лес, 3) скот караганы. Обнаружено по два случая передачи фактического размера и его уменьшения (литота). $34 \%$ сравнений эпоса использовано для описания движений и действий объекта, $26 \%$ - для создания зрительной картины. Также 5\% составили сравнения, передающие абстрагированные понятия физическую силу богатыря и чувство. Показатели текста «Боктуг-Кириш, Бора-Шэлей» немного отличаются, но доминирующей группой выступает также гиперболизация величины: передача численности и др. $-44,5 \%$, изображения $-14 \%$, действия $-24,5 \%$.

В якутском тексте «Кыыс Дэбилийэ» наиболее распространены сравнения, служащие для создания зрительных образов - 40\%. Вторыми по частотности использования выступают сравнения, служащие для описания действия $-31,5 \%$, далее сравнения, обозначающие численность и др. $-27 \%$ и выявлены два сравнения с абстрактными понятиями. В тексте «Могучий Эр Соготох» показатели сравнений по функции почти похожи: описание внешнего вида $-43 \%$, описание действия $-38 \%$, обозначение численности $-18 \%$, описание абстрактных понятий $-1 \%$.

Эти данные позволяют заключить, что сравнение в тувинском эпосе в основном привлекается для гиперболизации численности, размера, объема объекта, а в якутском олонхо главной функцией сравнений является передача яркого зрительного образа, создание более точной картины.

\section{Состав объектов и образов сравнения}

Основные объекты сравнения в якутском олонхо - внешний вид персонажей (главного героя, его коня, противников, людей, женщин-чудовищ, обитателей Нижнего мира) и их действия (как смотрят, ходят, спят, садятся на коня, борются, приходят в ярость, убивают и др.). Отмечается более частое использование сравнения при описании природы, чем в тувинском эпосе. Абстрактными понятиями, привлеченными в качестве объектов сравнения в якутском олонхо, являются сындааһын (выносливость), махталлаах баһыыба (благодарность; досл.: с благодарностью спасибо), харальан (слепота). 
В материале тувинского эпоса наблюдается заметное различие между текстами: в «Боктуг-Кириш, Бора-Шэлей» посредством сравнения чаще всего описывается внешний вид персонажей (главного героя, его коня, противников, толпы людей, скота и собак), а в «Хунан-Кара» преобладают объектыартефакты. Состав объектов сравнения в текстах отличается и отсутствием абстрактных понятий в последнем, в первом тексте это - чагыығ (наставление) и күш (сила). Также в «Боктуг-Кириш, БораШэлей» обнаружены алдын (золото) и мөңгүн (серебро), которые выступают самостоятельными объектами сравнения. В материале якутского эпоса подобный пример не был выявлен, в нем образ металла упоминается только в качестве эпитета объекта сравнения.

Таблица 2. Состав объектов сравнения в эпических текстах, в \% от общего кол-ва объектов.

Table 2. Composition of objects of comparison in epic texts, \% of the total number of objects.

\begin{tabular}{|l|c|c|c|c|}
\hline \multirow{2}{*}{} & \multicolumn{2}{|c|}{ Якутские эпосы } & \multicolumn{2}{|c|}{ Тувинские эпосы } \\
\cline { 2 - 5 } & $\begin{array}{c}\text { «Кыьс } \\
\text { Дэбилийэ» }\end{array}$ & $\begin{array}{c}\text { «Мггучй Эp } \\
\text { Соготох» }\end{array}$ & «Хунан-Кара» & $\begin{array}{c}\text { «Боктуг-Кириш, } \\
\text { Бора-Шэлей» }\end{array}$ \\
\hline Описание природы & 20 & 16 & 6 & 9 \\
\hline Внешний вид персонажей & 24 & 34 & 18 & 45 \\
\hline Артефакты & 14 & 5,5 & 34 & 20 \\
\hline Действия & 34 & 36 & 31 & 26 \\
\hline Абстрактные понятия & 8 & 8,5 & 11 & - \\
\hline
\end{tabular}

Прим.: жирным шрифтом выделены данные преобладающих тем объектов сравнения в эпосах.

Состав образов сравнения позволяет говорить о большей архаичности сравнений тувинского эпоса. Об этом свидетельствует, прежде всего, преобладание доли натурфактных образов, а также наличие образов металлов - ак мөңгұн (светлое серебро), каң-хая (стальная гора). В текстах выявлено множество различных образов «из мира природы» (Санжеева, 2011: 293), считающиеся наиболее ранними в постижении «непознанного» посредством сравнения: хүн (солнце), ай (луна), таңды (гора), Көгей (гора Когей), көк кожагар (островерхая синяя гора), хая-даштың (скалы-утесы), Кадыр тайга арны-биле (чистый склон отвесной скалы), арт (перевал), хөл, хөлчүк (озеро), далай (море), Эңгиргей тайганың бажыбиле (вершина тайги Энгиргей), арга-ла (густой лес), аяң (поляна), салгын (ветер), хат (порывистый вихрь) и т. д. Второе место по процентному соотношению в этом эпосе занимают биоморфные образы.

В якутском олонхо главным источником образов сравнения является животный мир, в котором отмечается большое разнообразие зверей и птиц. Следует отметить, что якутские сказители в большинстве случаев используют образы отдельных частей тела животных, нежели самих животных. При этом часто привлекается излюбленный в якутской эпической традиции прием детализации - в образах сравнения определяется пол и возраст животного, указывается его окрас или порода. Так, в рассмотренных текстах олонхо выявлены такие соматизмы, как сиэрэй тиин тинилэқэ (пятка серой белки), сачарыы табам кулгаақын сарыыта (кожа уха двухгодовалой самки оленя), арақас сылгым арқаһын түүтэ (загривок соловой лошади), алталаах атыыр сылгы таналайын кэрдииһэ (небные насечки шестилетнего жеребца), куба көтөрүм хотоқойун түүтэ (маховые перья лебедя-птицы), куба көтөрүм түөһүн унуоқа (грудная кость лебедя-птицы), собо балык ойоқоһун унуоқа (досл. реберные кости карася-рыбы) и др.

Выделяются также образы-артефакты, доля которых заметно выше в сопоставлении с тувинским материалом. Образы металлов в двух основных текстах отсутствуют, но выявлены в тексте олонхо «Хаан Дьаргыстай»: кылбальыйар кыһыл көмүс (сверкающее золото), көмүс (серебро), хорБолдьун (олово), дьэс алтан (красная медь), үрүн көмүс үрүмэтэ (серебряная корка) и др. (Хаан Дьаргыстай, 2016: 30, 71, $108,108,126)$. 
Таблица 3. Состав образов сравнения в эпических текстах, в \% от общего кол-ва образов. Table 3. Composition of images of comparison in epic texts, \% of the total number of images.

\begin{tabular}{|l|c|c|c|c|}
\hline \multirow{2}{*}{} & \multicolumn{2}{|c|}{ Якутские элосы } & \multicolumn{2}{|c|}{ Тувинские эпосы } \\
\cline { 2 - 5 } & «Кыьс Дэбилийэ» & $\begin{array}{c}\text { «огучий Эр } \\
\text { Соготох» }\end{array}$ & «Хунан-Кара» & $\begin{array}{c}\text { «Боктуг-Кириш, } \\
\text { Бора-Шэлей» }\end{array}$ \\
\hline Натурфакты & 28 & 24,5 & $\mathbf{5 0}$ & $\mathbf{4 5}$ \\
\hline Артефакты & 34 & 29,5 & 12 & 17 \\
\hline Биоморфизмы, соматизмы & $\mathbf{3 1}$ & $\mathbf{4 0}$ & $\mathbf{3 5}$ & 36 \\
\hline Действия & 5 & 5 & 1,5 & - \\
\hline Металлы & - & - & - & 2 \\
\hline Абстрактные понятия & 2 & 1 & 1,5 & - \\
\hline
\end{tabular}

Прим.: жирным шрифтом выделены данные наиболее популярных образов сравнения в эпосах.

\section{Основные устойчивые сравнения}

Как нам видится, некоторые устойчивые формулы, часто повторяясь при сказывании, принимают непосредственное участие в стилеобразовании эпического произведения. Они могут усилить героический тон эпоса, способствовать возвышенному стилю изложения (Львова, 2019: 130), или придать своеобразную окраску, как, например, в олонхо «Удаганки Уолумар и Айгыр» (Герасимова, Львова, 2016: 62): в этом олонхо обилие сравнений, изображающих внешний облик, одеяние, действия главных героинь - сестер шаманок, многочисленных представителей Нижнего мира и прочих духов, а также образы сакральных птиц (кукушки, ворона, лебедя), создают необычный «мрачный» стиль, близкий жанру современного хоррора, который в конечном итоге притупляет героику эпоса в целом.

В изучаемых текстах традиционно чаще повторяются сравнения, характеризующие главного героя. Сперва рассмотрим материал эпосов, в которых главным героем является мужчина. В якутском олонхо «Могучий Эр Соготох» выявлены два сравнения, повторяющиеся в тексте по 9 раз.

В первом передается ловкость героя олонхо, вскочившего на своего коня, с помощью сопоставления с глухарем:

Харалдыыктан көппүт

Хара улардаақар хапсақайдык

Ханха дьолуо ыныырыгар

Хап-бааччы хатана түстэ,

Токутар улар курдук

Чоноччу олорон кэбистэ
... проворней, чем черный глухарь, взлетевший с проталины, в крепкое седло ловко вскочил, словно токующий глухарь, откинув голову, горделиво уселся

(там же: 111).

Во втором сравнении гиперболизируется многочисленность родни и подчиненных богатыря:

Кинкир хара тыа курдук

Киэн урууларын ыныраннар,

Баай хара тыа курдук

Бар дьоннорун хомуйаннар, ...

(Каратаев, 1996: 144). словно деревья в дремучем лесу, многочисленных родственников собрав, словно деревья в густом лесу, всех сородичей собрав, ...

(там же: 145).

В тувинском эпосе «Хунан-Кара» 5 раз повторяется формула, сравнивающая богатыря с мчащимся быком и с выпущенной стрелой. Например: 
Кайыыртан келген, Кулуксаан буга сен, Кайыыртан келген, Кулбураан согун боор сен?

(Ооржак Ч.-Х., 1997: 130).
Ты откуда явился, [Будто] вырвавшийся бык?

Ты откуда явился,

[Будто] выскользнувшая стрела?

(там же: 131).

Функция данного параллелизма сравнений - передача большой скорости, неожиданности мгновенного появления героя.

Также привлекают внимание выражения, описывающие как ловко персонаж увертывается и передающие изобилие жизни в достатке:

\begin{tabular}{|c|c|}
\hline $\begin{array}{l}\text { Дээлдигенниң дезии-биле } \\
\text { Алдырбас, } \\
<\ldots \text {...> } \\
\text { Хартыганың кашпагайы-биле } \\
\text { Алдырбайн-даа турган иргин ийин } \\
\qquad \text { (Ооржак Ч.-Х., 1997: 218). }\end{array}$ & $\begin{array}{l}\text { Но [тот] увернулся } \\
\text { С быстротой коршуна ... } \\
<\ldots . \text { > } \\
\text { [Тот] увернулся } \\
\text { С проворством ястреба }\end{array}$ \\
\hline $\begin{array}{l}\text { Хараган дег малдыг, } \\
\text { Хая дег эттиг кижи болгай } \\
\text { (Ооржак Ч.-Х., 1997: 100). }\end{array}$ & $\begin{array}{l}\text { Ведь скота у него - что [зарослей] караганы, } \\
\text { Добра - со скалу } \\
\text { (там же: 101). }\end{array}$ \\
\hline
\end{tabular}

Выясняется, что в каждом эпосе подобран соответствующий образ сравнения, отражающий флору и фауну среды обитания народа, но тема и функции этих сравнений достаточно близкие: и в якутском, и в тувинском эпосах особо подчеркиваются ловкость и быстрота действий богатырей с привлечением образов птиц; собственность богатырей ассоциируется по численности с растительностью. Таким образом, в рассмотренных текстах основными устойчивыми сравнениями являются формулы, передающие физические данные и состоятельность героя (в нашем случае наличие у героя многочисленного народа и несметного богатства указывает именно на благосостояние богатыря), что акцентирует в эпосе такие «мужские» концепты, как «сила» и «власть».

Не менее интересно, что объектами основных устойчивых сравнений во второй паре эпосов «Кыыс Дэбилийэ» и «Боктуг-Кириш, Бора-Шэлей», в которых главными героями выступают женщинывоительницы, оказались глаза и взгляд персонажей. В тувинском эпосе выделяется формула изображения глаз героев посредством сравнения с озерцами:

Хөлчүк дег ала карактыг ...

(Ооржак M., 1997: 312).
С ясными, как озера, глазами ...

(там же: 313).

В тексте выявлено всего 8 вариантов этого сравнения, некоторые из них образуют двухчленный параллелизм со сравнением глаз героя с глазами мифического существа Хирээти. Эти формулы характерны как богатырю Боктуг-Кириш, так и его сестре Бора-Шэлей, которая выдает себя за своего брата. Функция этих сравнений - передача больших выразительных, ясных глаз, обладатель которых, несомненно, отличается такими качествами, как сообразительность и находчивость.

В якутском эпосе чаще всех (6 раз) повторяется с некоторыми вариациями следующее сравнение:

Өруөллээх манньыаты

Үрэйэ туппут курдук

Өгүрүк-төгүрүк көрө-көрө ... круглыми очами, словно серебряные монеты, которые рядом положены, поводя ...

(там же: 267). 
Это выражение применяется только в отношении главной героини Кыыс Дэбилийэ для изображения выразительного взгляда девушки, одновременно характеризующего её дерзский нрав и острый ум, а иногда передающего её внутреннее состояние в определенной ситуации - удивление, беспокойство, раздражение.

Для описания же героев мужского пола в этом эпосе употребляется другая формула, сравнивающая взгляд с кольцами уздечки для лошади:

Эрэһэлээх үүн тиэрбэһин курдук

Эриличчи көрөн ...

(Бурнашев, 1993: 104). глазами, подобными кольцам уздечки, зорко глядя ...

(там же: 105).

Как видно из рассмотренного материала, в эпосах особо выделяются (часто повторяются) сравнения, характеризующие гендерные черты главных героев. И в сопоставляемых текстах якутского и тувинского эпосов, в которых главная роль отводится женским персонажам, выделяется единый концепт «разум/мудрость». Героини эпосов достигают своих целей (одерживают победу над своими противниками, спасают своих соплеменников), в первую очередь, благодаря своим интеллектуальным способностям (особенно в тувинском сказании) и созидательной женской натуре (в якутском олонхо).

\section{Параллели в сравнениях}

Кроме рассмотренных выше устойчивых формул, аналогии в сравнениях установлены по образам сравнений и ассоциациям.

Параллели в образах сравнения. В якутском и тувинском эпосах используются универсальные образы сравнения, служащие своеобразными мерами объема или размера, это - «гора», «озеро» и «конская голова».

Образ горы (таңды/тайга - 'гора', тайга-таңды - 'гора-тайга', кара арга - 'горный лес', оорга тайгада - 'горная гряда', хая - 'скала', туруг - 'утес') является одним из главных образов сравнения тувинского эпоса, который символизирует собой величие, непробиваемость, устойчивость. В тувинских текстах сравнения с образом горы прежде всего служат для гиперболизации богатыря и его коня, для придания им исполинских размеров. Например:

Тайга-таңды ышкаш,

Кара аът тура

Дүжүп турган иргин ийин

(Ооржак Ч.-Х., 1997: 106; здесь и далее по тексту все курсивы в цитатах наши. - С. Л.).

Көгей дег эр бооп

Көстүп олуруп-тур
Он стал

Черным конем

Ростом с высокую гору-тайгу

(там же: 107).

Как [гора] Когей, богатырь

Так выглядеть стал

(там же: 313).

Титаническая битва противников уподобляется столкновению стальных скал:

Каң-хая

Каккылаштырган ышкаш ...

(Ооржак M., 1997: 218).
Как скалы стальные,

Столкнулись ...

(там же: 219).

Помимо этого, с помощью образа горы создается картина обилия яств и богатства персонажей, а образ скалы встречается в описании высоких, неприступных стен дворца противников:

Мен далай дег арагам,

Таңды дег эдим
Араги - с море,

Мяса - с гору 


\begin{tabular}{|c|c|c|}
\hline $\begin{array}{l}\text { Далай дегни ижип алган бис, } \\
\text { Таңды дегни чип алган бис } \\
\text { (Ооржак Ч.-Х., 1997: 110). }\end{array}$ & $\begin{array}{l}\text { С море мы выпили, } \\
\text { С гору поели }\end{array}$ & (там же: 111). \\
\hline (Ооржак Ч.-Х., 1997: 100). & Добра - со скалу & (там же: 101). \\
\hline (Ооржак Ч.-Х., 1997: 260). & $\begin{array}{l}\text { Ставки-дворца } \\
\text { [С оградой,] словно черная скала }\end{array}$ & (там же: 261). \\
\hline
\end{tabular}

Образ горы в рассмотренных текстах якутского олонхо встречается сравнительно реже, например, в «Могучий Эр Соготох» он содержится в описании чудовища - богатыря Нижнего мира, который страдает близорукостью и не замечает чего-либо размером даже с гору (Каратаев, 1996: 228). В другом тексте «Кыыс Дэбилийэ» скале уподобляется огромная якутская печь богатыря:

Тоқус кырыылаах

Турук хайа курдук

Суорба хаан оһоқун ... девятигранной, словно крутая скала, громадной почтенной печи ...

(там же: 113).

Вместо образа горы (хайа) в олонхо часто употребляются образы возвышенностей, меньших по объему: булгунньах (холм) и сыыр (горка). Вероятно, эти образы являются производными от образа горы и появились в более поздний период, когда основная масса якутов заселила центральную часть Якутии, где в рельефе местности преобладает равнинная низменность.

Образ озера в двух эпосах выполняет одинаковую функцию передачи большого размера (площади) предпочтительно «плоского» объекта округлой формы. Так, с помощью образа озера в обоих тувинских текстах изображается потник богатырского коня (чонак), а в якутском тексте «Кыыс Дэбилийэ» огромный бубен небесной шаманки (түөлбэ хаан дүнүр):

Хөл болган хөлбең кара чонактыг ...

(Ооржак Ч.-Х., 1997: 298).

Көлүйэ күөл сақа

Түөлбэ хаан дүнүрүн ...
Широкий, как озеро, черный потник имел ...

(там же: 299).

подобный круглому озерку огромный почтенный бубен ...

(там же: 253).

Образ озера в эпосах привлекается также для описания глаз персонажей, но с отличием в семантическом содержании. Как уже было упомянуто, в тувинском эпосе ясные глаза главного героя описываются с помощью образа озера. В якутском же эпосе этот образ в большинстве случаев носит отрицательную семантику и служит для изображения непривычно большого, одинокого глаза, пустого «стеклянного взгляда» чудовища. Кроме этого, в олонхо часто встречается образ зимнего обледеневшего озера, с резко пробившейся надледной водой (Каратаев, 1996: 126), который также служит для изображения безобразного ока посреди лба чудовища.

Образ «конская голова» ранее был выявлен в алтайском, хакасском и шорском эпосах с идентичным объектом сравнения «золотая кукушка», а в якутском олонхо этот образ привлекается для передачи размера различных объектов - огнива, кулака и даже абстрактного понятия «счастье» (Lvova, 2020: 140-142). В тувинском сказании «Боктуг-Кириш, Бора-Шэлей» 4 раза в точности повторяется устойчивая формула, передающая величину золота посредством образа конской головы. Здесь для сопоставления приведем пример из якутского олонхо «Хаан Дьаргыстай» - сравнение богатырского огнива с конской головой по величине, широко распространенное в якутской эпической традиции:

Аът бажы дег алдын,

Бөрү бажы дег мөңгүн
Золота - с конскую голову,

Серебра - с волчью голову 
Аллаах ат баһын сақа

Ала чокуурдаан хататтаах

(Хаан Дьаргыстай, 2016: 16).
С голову резвого коня

Пестрое кремневое огниво имеет

(перевод наш. - С. Л.).

Если в якутском эпосе произошла полная деактуализация исходного объекта сравнения, то тувинскому эпосу, вероятно, удалось сохранить периферийную часть объекта (то есть эпитет «золотой»), преобразив её в самостоятельный объект сравнения.

Ассоциативные параллели. Ассоциация «народ - лес», которая была отмечена в якутском эпосе «Могучий Эр Соготох» сопоставляется нами со сравнением тувинского текста «Боктуг-Кириш, БораШэлей»:

\begin{tabular}{|c|c|}
\hline $\begin{array}{l}\text { Кинкир хара тыа курдук } \\
\text { Киэн урууларын ыныраннар, } \\
\text { Баай хара тыа курдук } \\
\text { Бар дьоннорун хомуйаннар, ... }\end{array}$ & $\begin{array}{l}\text { словно деревья в дремучем лесу, } \\
\text { многочисленных родственников собрав, } \\
\text { словно деревья в густом лесу, } \\
\text { всех сородичей собрав, ... } \\
\text { (там же: } 145) .\end{array}$ \\
\hline (Ооржак М., 1997: 488). & $\begin{array}{r}\text { Людей же - как [деревьев] в темном горном лесу } \\
\ldots \\
\text { (там же: 489). }\end{array}$ \\
\hline
\end{tabular}

Здесь совпадают не только объекты и образы сравнения, но и эпитет хара/кара - 'черный' Этот эпитет способствует созданию образа дремучего, темного от густоты леса, который передает многочисленность, плотность стоящих толпой людей.

Общее для якутского, хакасского и шорского эпосов сравнение, передающее величину камня посредством образа коровы, обнаружено в тувинском тексте «Хунан-Кара». Но тувинский вариант сравнения имеет одно отличие: если в материалах других эпосов речь идет о черном камне (в якутском олонхо цвет камня либо черный, либо цвет не упоминается), то в тувинском варианте объектом сравнения выступает камень белого цвета. Вместе с тем, на материале сопоставляемых нами текстов выявлена другая параллель - в тувинском и якутском эпосах одинаково конкретизируются образы сравнения через указание трехлетнего возраста коровы. Функцией такого образа является передача более точной величины камня:

Хунан инек дег

Ак дажы-биле ...
Белым камнем

С корову-трехлетку...

(Ооржак Ч.-Х., 1997: 178).

(там же: 179).

Бургунас ынах сақа

Буотама таас буркуннаммыта, ...

(Каратаев, 1996: 96).
С трехгодовалую телку каменные завалы

Сильным ветром нанесло, ...

(там же: 97).

В тексте «Боктуг-Кириш, Бора-Шэлей» это сравнение не встречается, в нем величина камней передается через образы зайца, коленной чашечки зайца или овцы, а образ коровы-трехлетки привлекается для обозначения размеров «хлопьев белой пены», которые падают из подмышек героев при сильном напряжении:

Ийи колдуундан

Ийи хунан инек дег ак көвүк уштунуп чаштап, ... (Ооржак M., 1997: 404).
Из обеих подмышек ее

Белые [хлопья] пены с двух коров-трехлеток стали падать-слетать, ...

В обоих текстах тувинского эпоса отмечается устойчивая формула, содержащая сопоставление седла коня с перевалом: 
Арm болган

Аңгайган, алдын-мөңгүн

Эзер, чүгенин, ...
Золоченое-посеребрённое

Седло с глубоким изгибом,

Как [падь между] перевалами, ...

(там же: 119).

Apm болган аңгайган-кеңгейген эзерлиг

(Ооржак M., 1997: 298). (там же: 299)

Эти сравнения придают образу драгоценного богатырского седла еще большую благородность и величие.

В большинстве якутских олонхо седло богатырского коня описывается посредством метафоры с привлечением образа неба, что подчеркивает небесное происхождение коня, но в дополнительном материале нашего исследования - в тексте «Эриэдэл Бэргэн», первой в истории записи олонхо (Иванов, Корякина, Анисимов, 2018: 32), было выявлено сравнение, в котором седло коня сопоставляется с булгунньах (холмом):

Босхо булгунньађы ууран кээспит курдук ыныырдаах

(Миддендорф, 1911: 473).
Будто оторвали и положили холм - подобное седло имеет ...

(перевод наш. - С. Л.).

Как было отмечено выше, образ холма в якутском эпосе часто выполняет такую же функцию, что и образ горы в тувинском. Несомненно, эти сравнения перекликаются, так как в обоих сопоставлениях происходит гиперболизация размера и передается очертание формы седла. Однако стоит отметить, что якутский образ седла, по сравнению с тувинским «золоченым-посеребрённым» вариантом, стал намного приземленным за счет образа холма северной природы, скромного по масштабу и колориту.

Также общими в якутском и тувинском эпосах являются сравнения: большой скорости и внезапности появления героя со скоростью выпущенной стрелы или с ветром, маленькой щели с ушком иглы, зуба отрицательного персонажа с заступом, готовых к схватке противников с противопоставленными быками.

\section{Особенности сравнений}

Специфика сравнений родственных эпосов проявлена в составе их образов. В каждом эпосе можно выделить группу, выражающую национальное своеобразие путем отражения культурно-бытовых реалий, это - образы предметов и понятий, которые есть только у народа-носителя. Обычно ими становятся артефакты (бытовые предметы, кухонная утварь и еда, украшения и др.), исключая из них боевые оружия. Образы артефактов чаще всего привлекаются для описания внешностей различных персонажей. Так, в рассмотренных двух якутских олонхо такую группу составляют: различная домашняя утварь из бересты или дерева (атыйах, тордуйа, холлобос, чабычах, ыаБас, кытыйа), пешня закаленная ${ }^{1}$ (хатарыылаах анньыы), коса, изготовленная мастерами Верхоянья ${ }^{2}$ (дьааны хатыыра), емкость для сбора коровьего навоза (саах кэлиитэ), тунгусские лыжи (тонус киһи туут хайыhapa), тунгусская берестяная юрта (тонус киһи туос ураһата), стог сена (суугулаах/сыарБалаах от), копна сена (бугул); орнамент на замше (сарыы таналай), серебряная бляха на рогатой шапке с пером (mуоhaxта), витая

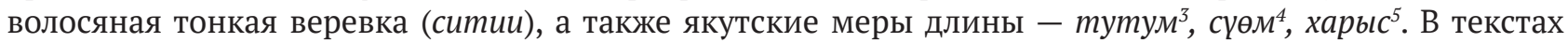

\footnotetext{
${ }^{1}$ Инструмент для прорубанья льда в зимний период, представляющий собой заостренный лом из закаленной стали с деревянной ручкой.

${ }^{2}$ Верхоянье - Янский край, ныне территория Верхоянского района, расположенная на севере Якутии. Известно, что «в кочковатых болотистых лугах Янского края» при сенокосе использовали особый вид косы-горбуши (Бурнашев, 1993: 306).

${ }^{3}$ Тутум - старинная якутская мера длины, равная высоте сложенных в кулак пальцев руки (Винокуров, 2017: 28).

${ }^{4}$ Сүөм - старинная якутская мера длины, равная расстоянию от кончиков вытянутого большого пальца до кончиков вытянутого указательного пальца руки; соответствует русской мере «малая пядь» (Винокуров, 2017: 28).

${ }^{5}$ Харыс - старинная якутская мера длины, равная расстоянию от кончиков вытянутого большого пальца до кончиков вытянутого среднего пальца руки; соответствует русской мере длины «большая пядь» (Винокуров, 2017: 30).
} 
тувинского эпоса выявлены образы бабки-кости (кажык), казана, в котором собирают золу (хүл узар казан), тайги Энгиргей, горы Когей и глаз мифической птицы Хирээти.

Сравнения с элементами, определяющими отличительные черты места обитания народа, также являются характерными для национального эпоса. Сведения о среде обитания носителя эпоса содержат образы растений (фитонимов), животных (зоонимов) и птиц (орнитонимов), в том числе образы-соматизмы. В якутском олонхо отмечены образы дьааны болбуктата (янского кедрового стланика), хастаабыт/суллаабыт тиит (очищенной от коры/окоренной лиственницы), бысталаабыт тиит (лиственничных обрубков), кинкир хара тыа (густых таежных лесов); кырынаас (горностая), үүскиис тириитэ (собольего меха), сиэрэй тиин тилэқэ (пятки серой белки), сачарыы табам кулгаабын сарыыта (уха оленя), бөрө (волка); хара хабдьы (черной куропатки), ұрүн куртуйах (белого тетерева), хара улар (черного глухаря), эрдэқэс улар түөһүн түүтэ (грудного оперенья самки глухаря), анды кыьлл хабабын түүтэ (брюшного оперенья турпана), куба көтөрүм хотобойун түүтэ (маховых перьев лебедя), субан туруйа куолайа (горла вольного журавля), хонор хаас (большого сибирского гуся-гуменника), собо балык ойобоһун унуоба (ребры карася), сыалыһар быара (налимьей печени). В тувинском эпосе встречаются образы хараган (зарослей караганы), өл хаак (сырой лозы), хөвең (хлопка); теве (верблюда), кужан (барана), хой (овцы), булан (самки лося), чары (самца оленя), кодан (зайца), кодан довуу (коленной чашечки зайца), бөру бажы (волчьей головы); дээлдиген (коршуна), хартыга (ястреба); кымыскаяк-ла (муравьев), сээк-ле (мух), маас (овода).

\section{Заключение}

В ходе сопоставительного изучения материалов родственных эпосов установлены количества использования сравнений без повторов, которые равны в якутских текстах: «Могучий Эр Соготох» (6377 стихотворных строк) 74 единицам, «Кыыс Дэбилийэ» (4969 стихотворных строк) - 134; в тувинских текстах: «Хунан-Кара» (5442 стихотворные строки) - 65, «Боктуг-Кириш, Бора-Шэлей» (5061 стихотворных строк) - 45. Показатели частоты сравнений, повтора и доли параллелизации сравнений оказались чуть выше в якутском материале. Во всех четырех текстах сравнения преимущественно (более 90\%) оформляются в двухчленные параллелизмы. Максимальное количество употребления одного устойчивого сравнения составило 9 раз в якутском тексте «Могучий Эр Соготох» и 8 раз - в тувинском тексте «Боктуг-Кириш, Бора-Шэлей». Таким образом, сравнение широко употребляется в обоих традициях эпосов.

Сравнение в тувинском эпосе в основном привлекается для гиперболизации численности, размера, объема объектов, а в якутском олонхо главной функцией сравнений является передача детализированного зрительного образа. Выявлена общность в тематическом содержании объектов и образов сравнения, отличие наблюдается в их процентном соотношении. Так, помимо того, что главным объектом сравнений в двух сопоставляемых эпосах выступает внешний вид персонажей, в якутском олонхо посредством сравнения часто описываются действия и движения персонажей, а в тувинском более предпочтительны объекты-артефакты. В составе образов сравнения тувинского эпоса преобладают образы-натурфакты, в якутском олонхо же главным источником образов сравнения является животный мир северной природы. В целом, сравнения тувинского эпоса определены нами более архаичными, на том основании, что в рассмотренных тувинских текстах преобладают натурфактные образы, отмечены образы-металлы, а также сравнения чаще выполняют гиперболизирующую функцию.

Далее установлены параллели в сравнениях эпосов. Так, в якутском и тувинском эпосах обнаружены универсальные образы сравнения, служащие своеобразными мерами объема или размера («гора», «озеро», «конская голова»). Во-вторых, обозначены сходные ассоциации при сравнениях толпы народа с лесом, седла с перевалом, камня с коровой по величине, столкновения противников со столкновением скал, противников перед схваткой с разъяренными быками, скорости передвижения героя с выпущенной стрелой, маленькой щели с ушком иглы и безобразного зуба персонажа с заступом. В-третьих, при анализе основных устойчивых сравнений были выявлены общие концепты для эпосов - «силы» и «власти» в текстах с главным героем мужчиной и «разума/мудрости» в текстах, в которых основную роль выполняют женские персонажи. Это указывает на сходные гендерные стереотипы в двух разных культурах, которые отражают «нормы и стандарты мужского и женского поведения, существующие в обыденном сознании» (Егорова, Кондакова, Кужугет, 2020: 21). Можно сказать, что якуты и тувинцы сохранили в эпосах единые идеалы женственности и мужественности.

Специфика сравнений родственных эпосов проявлена в составе их образов - в каждом эпосе установлены группы характерных образов, отражающих культурно-бытовые реалии и флору и фауну 
среды обитания народа-носителя эпоса. Особенно отличаются якутские сравнения, в которых часто привлекаются образы отдельных частей тела животных (то есть образы-соматизмы) и используется прием детализации путем указания породы, окраса, пола или возраста в образе животного.

Таким образом, можно заключить, что сравнения в двух родственных эпосах имеют больше общих черт, чем отличий по всем рассмотренным параметрам (по характеру их применения, по составу объектов и образов, по семантике и функции). В процессе своего исторического развития эпосы обогатили художественное содержание сравнений самобытными образами, при этом сохранили основные концепты и немало исходных, на наш взгляд, элементов сравнений.

\section{СПИСОК ЛИТЕРАТУРЫ}

Аникин, В. П. (2007) Теория фольклора. М. : КДУ. 432 с.

Борисов, Ю. П. (2020) Параллели эпических формул в якутском олонхо и тувинском эпосе: сравнительный аспект // Новые исследования Тувы. № 4. С. 250-260. DOI: www.doi.org/10.25178/nit.2020.4.17

Бурнашев, Н. П. (1993) Кыыс Дэбилийэ: якутский героический эпос / Памятники фольклора народов Сибири и Дальнего Востока. Т. 4. Новосибирск : Наука. 330 с.

Винокуров, В. В. (2017) Пространственно-временные представления и единицы длины и времени в якутском олонхо. Якутск : Издательский дом СВФУ. 64 с.

Герасимова, Л. Н., Львова, С. Д. (2016) Способы выражения сравнения в олонхо «Удаганки Уолумар и Айгыр» и «Ёлбёт Бэргэн» // Вестник Северо-Восточного федерального университета имени М. К. Аммосова : Серия Эпосоведение. № 2 (02). С. 52-64. DOI: www.doi.org/10.25587/SVFU.2016.2.10878

Егорова, А. И., Кондакова, А. П., Кужугет, М. А. (2020) Гендерные стереотипы в тувинских пословицах и поговорках // Новые исследования Тувы. № 1. С. 19-34. DOI: www.doi.org/10.25178/nit.2020.1.2

Иванов, В. Н., Корякина, А. Ф., Анисимов, Р. Н. (2018) Из истории изучения якутского героического эпоса олонхо (XVIII - начало XX веков) // ФИЛOLOGOS. № 36 (1). C. 30-36. DOI: www.doi.org/10.24888/2079-2638-2018-36-130-36

Каратаев, В. О. (1996) Якутский героический эпос. «Могучий Эр Соготох» / Памятники фольклора народов Сибири и Дальнего Востока. Т. 10. Новосибирск : Наука. 440 с.

Корякина, А. Ф. (2020) Аналогии в якутском олонхо и тувинском эпосе: сюжетно-композиционный строй, мотивы (на материале эпосов «Нюргун Боотур Стремительный» К. Г. Оросина и «Хунан-Кара» Чанчы-Хоо Ооржак // Научный диалог. № 5. С. 303-319. DOI: https://doi.org/10.24224/2227-1295-2020-5-303-319

Кудияров, А. В. (2002) Художественно-стилевые традиции эпоса монголоязычных и тюркоязычных народов Сибири. М. : ИМЛИ РАН. 329 с.

Литературный энциклопедический словарь (1987) / под общ. ред. В. М. Кожевникова, П. А. Николаева. М. : Советская энциклопедия. 751 с.

Львова, С. Д. (2019) Сравнения в якутском и алтайском эпосах (на материале олонхо «Могучий Эр Соготох» и кай чёрчёк «Маадай-Кара») // Вестник Северо-Восточного федерального университета имени М. К. Аммосова. Серия Эпосоведение. № 3 (15). С. 126-139. DOI: www.doi.org/10.25587/SVFU.2019.15.36605

Львова, С. Д. (2020) О сравнениях якутского и шорского эпосов: сравнительный аспект // Ысыах Олонхо в Олёкме: пути возрождения, популяризации и сохранения эпического наследия: сборник тезисов по материалам XI Республиканской научно-практической конференции (Олекминск, 8-10 февраля 2020 г.) / отв. ред. А. Н. Жирков; сост. Р. В. Корякина, Е. Е. Жиркова. Якутск : Алаас. 288 с. С. 92-96.

Миддендорф, А. Ф. (1911) Эриэдэл-бэргэн // Образцы народной литературы якутов / под ред. Э. К. Пекарского. Вып. 5. Ч. 1. Санкт-Петербург : Типография Императорской Академии наук. 475 с. С. 473-474.

Орус-оол, С. М. (2001) Тувинские героические сказания. Текстология, поэтика, стиль. М. : Макс Пресс. 422 с.

Ооржак, М. Н. (1997) Боктуг-Кириш, Бора-Шэлей // Тувинские героические сказания / Памятники фольклора народов Сибири и Дальнего Востока. Т. 12. Новосибирск : Наука. 584 с. С. 298-527.

Ооржак, Ч.-Х. Ч. (1997) Хунан-Кара // Тувинские героические сказания / Памятники фольклора народов Сибири и Дальнего Востока. Т. 12. Новосибирск : Наука. 584 с. С. 54-297.

Пухов, И. В. (2004) Героический эпос алтае-саянских народов и якутские олонхо. Якутск : Изд-во СО РАН, Як. филиал. 328 с.

Саввинова, Г. Е. (2020) О поэтике олонхо «Нюргун Боотур Стремительный» П. А. Ойунского и тувинских героических эпосов // Oriental Studies. T. 13. № 4. C. 1155-1166. DOI: www.doi.org/10.22162/2619-0990-2020-50-4-11551166.

Санжеева, Л. Ц. (2011) Поэтика фольклорного текста (на материале бурятского эпоса) : дисс.... Д. филол. н. УланУдэ. 358 с. 
Селиванов, Ф. М. (1977) Поэтика былин. М. : Изд-во Московского университета. 128 с.

Хаан Дьаргыстай: олонхо (2016) / сост. В. В. Илларионов. Дьокуускай : Алаас. 232 с. (На як. яз.)

Хертек, Л. К. (2018) Функционирование сравнений в текстах тувинских героических сказаний // Вестник Тувинского государственного университета. №1. Социальные и гуманитарные науки. № 1 (36). С. 43-48.

Gerasimova, L. N., Lvova, S. D. (2018) Structural and Functional Features of Comparison Methods in the Yakut and Khakass Epics // Journal of History Culture and Art Research. Vol. 7, No. 3. P. 88-98. DOI: http://dx.doi.org/10.7596/taksad. v7i3.1721

Lvova, S. D. (2020) Biomorphic images of comparison in Yakut Olonkho and other Turkic epics of Siberia // Agathos: An International Review of the Humanities and Social Sciences. Vol. 11, Iss. 2 (21). Pp. 133-149.

Дата поступления: 26.01.2021 2.

\section{REFERENCES}

Anikin, V. P. (2007) Teoriia fol'klora [A theory of folklore]. Moscow, KDU Publ. 432 p. (In Russ.).

Borisov, Yu. P. (2020) Paralleli epicheskikh formul v iakutskom olonkho i tuvinskom epose: sravnitel'nyi aspekt [Parallels of epic formulas in the Yakut olonkho and Tuvan epics: a comparative aspect]. New Research of Tuva, no. 4, pp. 250-260. (In Russ.). DOI: www.doi.org/10.25178/nit.2020.4.17

Burnashev, N. P. (1993) Kyys Debiliie: iakutskii geroicheskii epos / Pamiatniki fol'klora narodov Sibiri i Dal'nego Vostoka [Kyys Debiliie: Yakut heroic epic / folklore texts of the peoples of Siberia and the Far East]. Vol. 4. Novosibirsk, Nauka Publ. 330 p. (In Yakut and Russ.).

Vinokurov, V. V. (2017) Prostranstvenno-vremennye predstavleniia i edinitsy dliny i vremeni v iakutskom olonkho [Spatiotemporal representations and units of length and time in the Yakut olonkho]. Yakutsk, NEFU Publ. 64 p. (In Russ.).

Gerasimova, L. N. and L'vova S. D. (2016) Sposoby vyrazheniia sravneniia v olonkho "Udaganki Uolumar i Aigyr” i "Elbet Bergen" [Ways of expressing comparison in olonkho "Udaganki Walumar and Aigyr" and "Yolbet Bergen”]. Vestnik of NorthEastern Federal University. Series Epic studies, no. 2, pp. 52-64. (In Russ.). DOI: www.doi.org/10.25587/SVFU.2016.2.10878

Egorova, A. I., Kondakova, A. P. and Kuzhuget, M. A. (2020) Gendernye stereotipy v tuvinskikh poslovitsakh i pogovorkakh [Gender stereotypes in Tuvan proverbs and sayings]. New Research of Tuva, no. 1, pp. 19-34. (In Russ.). DOI: www. doi.org/10.25178/nit.2020.1.2

Ivanov, V. N., Koriakina, A. F. and Anisimov, R. N. (2018) Iz istorii izucheniia iakutskogo geroicheskogo eposa olonkho (XVIII - nachalo XX vekov) [From the history of the study of the Yakut heroic epic olonkho: $18^{\text {th }}-$ early $20^{\text {th }}$ century]. FILOLOGOS, no. 36 (1), pp. 30-36. (In Russ.). DOI: www.doi.org/10.24888/2079-2638-2018-36-1-30-36

Karataev, V. O. (1996) Iakutskii geroicheskii epos. "Moguchii Er Sogotokh” / Pamiatniki fol'klora narodov Sibiri i Dal'nego Vostoka [Yakut heroic epic. "Mighty Er Sogotokh" / folklore texts of the peoples of Siberia and the Far East]. Vol. 10. Novosibirsk, Nauka Publ. 440 p. (In Yakut and Russ.).

Koryakina, A. F. (2020) Analogii v iakutskom olonkho i tuvinskom epose: siuzhetno-kompozitsionnyi stroi, motivy (na materiale eposov "Niurgun Bootur Stremitel'nyi” K. G. Orosina i “Khunan-Kara” Chanchy-Khoo Oorzhak [Analogies in Yakut Olonkho and Tuvan Epos: The structure of the plot and composition, and motifs in the epics "Nyurgun Bootur the Swift” by G. K. Orosin and “Hunan-Kara” by Changchi-Khoo Oorzhak)]. Nauchnyi dialog, no. 5, pp. 303-319. (In Russ.). DOI: https://doi.org/10.24224/2227-1295-2020-5-303-319

Kudiyarov, A. V. (2002) Khudozhestvenno-stilevye traditsii eposa mongoloiazychnykh i tiurkoiazychnykh narodov Sibiri [Artistic and stylistic traditions of the epic of the Mongol-speaking and Turkic-speaking peoples of Siberia]. Moscow, IMLI RAN Publ. 329 p. (In Russ.).

Literaturnyi entsiklopedicheskii slovar' [An encyclopedic dictionary of literature] (1987). Ed. by V. M. Kozhevnikov and P. A. Nikolaev. Moscow, Sovetskaia entsiklopediia Publ. 751 p. (In Russ.).

L'vova, S. D. (2020) O sravneniiakh iakutskogo i shorskogo eposov: sravnitel'nyi aspekt [On comparisons in the Yakut and Shor epics: a comparative aspect]. In: Ysyakh Olonkho v Olekme: puti vozrozhdeniia, populiarizatsii $i$ sokhraneniia epicheskogo naslediia [Ysyakh Olonkho in Olekma: ways of reviving, popularizing and preserving the epic heritage]: Abstracts of papers presented at the $11^{\text {th }}$ Republican Research Conference (Olekminsk, February 8-10, 2020)] / ex. ed. A. N. Zhirkov; comp. by R. V. Koryakina and E. E. Zhirkova. Yakutsk, Alaas Publ. 288 p. Pp. 92-96. (In Russ.).

L'vova, S. D. (2019) Sravneniia v iakutskom i altaiskom eposakh (na materiale olonkho "Moguchii Er Sogotokh" i kai cherchek "Maadai-Kara") [Comparisons in the Yakut and Altai epics: the cases of the olonkho "Mighty Er Sogotokh" and the kai churchyok “Maadai-Kara”)]. Vestnik of North-Eastern Federal University. Series Epic studies, no. 3, pp. 126-139. (In Russ.). DOI: www.doi.org/10.25587/SVFU.2019.15.36605

Middendorf, A. F. (1911) Eriedel-bergen. Obraztsy narodnoi literatury iakutov [Samples of the Yakut folk literature] / Ed. by E. K. Pekarsky. Issue 5, part 1. St. Petersburg, Printing house of the Imperial Academy of Sciences. 475 p. Pp. 473-474. (In Yakut). 
Orus-ool, S. M. (2001) Tuvinskie geroicheskie skazaniia (tekstologiia, poetika, stil') [Tuvan heroic legends (textology, poetics, style)]. Moscow, MAKS Press. 422 p. (In Russ.).

Oorzhak, M. N. (1997) Boktug-Kirish, Bora-Shelei. In: Tuvinskie geroicheskie skazaniia / Pamiatniki fol'klora narodov Sibiri i Dal'nego Vostoka [Tuvan heroic tales / folklore texts of the peoples of Siberia and the Far East]. Vol. 12. Novosibirsk, Nauka Publ. 584 p. Pp. 298-527. (In Tuv. and Russ.).

Oorzhak, Ch.-Kh. Ch. (1997) Khunan-Kara. In: Tuvinskie geroicheskie skazaniia / Pamiatniki fol'klora narodov Sibiri i Dal'nego Vostoka [Tuvan heroic tales / folklore texts of the peoples of Siberia and the Far East]. Vol. 12. Novosibirsk, Nauka Publ. 584 p. Pp. 54-297. (In Tuv. and Russ.).

Pukhov, I. V. (2004) Geroicheskii epos altae-saianskikh narodov i iakutskie olonkho [Heroic epic of the Altai-Sayan peoples and the Yakut olonkho]. Yakutsk, SO RAN Publ., Yakut filial. 328 p. (In Russ.).

Savvinova, G. E. (2020) O poetike olonkho "Niurgun Bootur Stremitel'nyi” P. A. Oiunskogo i tuvinskikh geroicheskikh eposov [Platon Oyunsky's Olonkho "Nurgun Bootur the Swift” and Tuvan Heroic Epics: Poetics Revisited]. Oriental Studies, vol. 13, no. 4, pp. 1155-1166. (In Russ.). DOI: https://doi.org/10.22162/2619-0990-2020-50-4-1155-1166

Sanzheeva, L. Ts. (2011) Poetika fol'klornogo teksta (na materiale buriatskogo eposa) [Poetics of folklore text: the case of the Buryat epic)]. Diss.... Doctor of Philological Sciences. Ulan-Ude. 358 p. (In Russ.).

Selivanov, F. M. (1977) Poetika bylin [Poetics of bylinas]. Moscow, Izd-vo Moskovskogo universiteta. 128 p. (In Russ.).

Khaan D'argystai: olonkho (2016) / comp. by V. V. Illarionov. Yakutsk, Alaas Publ. 232 p. (In Yakut)

Khertek, L. K. (2018) Funktsionirovanie sravnenii v tekstakh tuvinskikh geroicheskikh skazanii [Functioning of comparisons in the texts of Tuvan heroic legends]. Vestnik Tuvinskogo gosudarstvennogo universiteta, no. 1, Sotsial'nye i gumanitarnye nauki, no. 1, pp. 43-48. (In Russ.).

Gerasimova, L. N. and Lvova, S. D. (2018) Structural and Functional Features of Comparison Methods in the Yakut and Khakass Epics. Journal of History Culture and Art Research, vol. 7, no. 3, pp. 88-98. DOI: http://dx.doi.org/10.7596/taksad. v7i3.1721

Lvova, S. D. (2020) Biomorphic images of comparison in Yakut Olonkho and other Turkic epics of Siberia. Agathos: An International Review of the Humanities and Social Sciences, vol. 11, iss. 2, pp. 133-149.

Submission date: 26.01.2021. 